\title{
ANALIZA PORÓWNAWCZA BADAŃ DELPHI DOTYCZĄCYCH INNOWACYJNOŚCI WIELKOPOLSKI
}

Streszczenie. W artykule przedstawiono analizę porównawczą wyników badań Delphi przeprowadzonych w latach 2010 i 2014. Badania dotyczyły problematyki innowacyjności Wielkopolski i możliwości tworzenia sieci gospodarczych, szczególnie w perspektywie roku 2030. W ocenie wyników wykorzystano analizę korespondencji i analizę czynnikową.

Słowa kluczowe: foresight; badania Delphi; innowacyjność

JEL: O18, O38, P48

\section{WPROWADZENIE}

W latach 2009-2011 w Politechnice Poznańskiej realizowano projekt „,Foresight «Sieci gospodarcze Wielkopolski» - scenariusze transformacji wiedzy wspierające innowacyjną gospodarkę", współfinansowany przez UE w ramach Programu Operacyjnego Innowacyjna Gospodarka. Niektóre analizy o charakterze poznawczym są kontynuowane w ramach działalności statutowej Wydziału Inżynierii Zarządzania Politechniki Poznańskiej w temacie: Foresight - sieci gospodarcze Wielkopolski (Wyrwicka, 2014).

Badania dotyczące twórczego kształtowania przyszłości typu foresight są odpowiedzią na ciągłe zmiany zachodzące zarówno wewnątrz regionów, jak i w ich otoczeniu. Foresight umożliwia uprzedzanie różnych możliwych wariantów przyszłości i zapobiegliwe przygotowanie reakcji na zdarzenia najbardziej prawdopodobne (Safin, 2011: 15-16). Jego efektem jest budowanie wspólnych scenariuszy rozwoju.

Według I. Milesa, foresight to systematyczny, partycypacyjny, ukierunkowany na gromadzenie wiedzy dotyczącej przyszłości proces budowania średnioterminowej i długoterminowej wizji, zorientowany na teraźniejsze decyzje i mobilizowanie wspólnych działań (Gavigan i in., 2001: 3). Pięć głównych elementów

\footnotetext{
* Politechnika Poznańska, Wydział Inżynierii, Zarządzania, Katedra Zarządzania i Systemów Informatycznych.

** Politechnika Poznańska, Wydział Inżynierii, Zarządzania, Katedra Zarządzania Produkcją i Logistyki.
} 
foresightu to antycypacja oraz projektowanie przyszłości, partycypacja, tworzenie sieci społecznych, strategiczna wizja, a także aktualne decyzje i ich realizacja. Jest to więc rodzaj usystematyzowanego myślenia, którego istotą jest bardziej kreowanie oraz współtworzenie przyszłości niż tylko jej przewidywanie i zarządzanie nią (Rogut, Piasecki, 2011: 33).

Zbiór metod, które są przeznaczone do stosowania w badaniach foresight, jest różnorodny $\mathrm{i}-\mathrm{w}$ związku $\mathrm{z}$ ciągłym jego rozwojem metody - jest wciąż otwarty (Nazarko, 2013: 31). Warto podkreślić, że foresight realizowany jest przy wykorzystaniu różnorodnych narzędzi, zarówno ściśle naukowych, jak i heurystycznych, bazujących na intuicji eksperckiej (Magruk, Jańczuk, 2009: 382). Najbardziej rozpowszechniona jest zaproponowana przez R. Poppera typologia metod (tzw. diament metodyczny foresightu), obejmująca cztery wymiary: kreatywność, wiedzę ekspercką, interakcję oraz fakty (Popper, 2009). Dobór metod do konkretnego badania foresight jest celowy i wynika z przyjętej metodyki. Zawsze istotne jest jednak w badaniach foresight odkrywanie dla różnych grup społecznych wspólnych przestrzeni myślenia o przyszłości. Oznacza to potrzebę prowadzenia cyklicznych badań, umożliwiających monitorowanie ewolucji ocen dotyczących teraźniejszości oraz opinii o przyszłości. Takie analizy można realizować, wykorzystując metodę Delphi, która przewiduje zarówno ocenę bieżącej sytuacji, jak i wskazanie przez eksperta kierunku przewidywanego rozwoju zjawiska opisywanego tezą.

Wyniki badań Delphi w skojarzeniu z danymi pozyskanymi innymi metodami są użyteczne przy tworzeniu scenariuszy zmian rozwojowych.

Opisane poniżej badania metodą Delphi, realizowane z intencją rozpoznania sytuacji proinnowacyjnego rozwoju Wielkopolski, przeprowadzono po raz pierwszy w roku 2010 i powtórzono w 2014. Bazowano na tym samym zestawie tez, a zapytania kierowano do tej samej grupy ekspertów. Celem analiz było pozyskanie opinii na temat zmian w ocenach sytuacji opisanych tezami, zwłaszcza w perspektywie przyszłości wskazanej w obu badaniach na rok 2030.

\section{BADANIA DELPHI}

Metoda Delphi została wypracowana w amerykańskim ośrodku studiów strategicznych RAND Corporation, w Santa Monica w Kalifornii, na początku lat pięćdziesiątych XX wieku. Nazwę nadał jej filozof A. Kaplan, natomiast jej podstawy opracowali dwaj matematycy - N.C. Dalkey oraz O. Helmer (Dalkey, Helmer, 1963: 458). Delphi to jakościowa metoda łącząca wiedzę i opinie ekspertów w celu osiągnięcia świadomego konsensusu w kwestii złożonego problemu. Jej istotą jest celowy proces komunikacji grupowej niezależnych osób, które dążą do rozwiązania złożonego problemu. Cel ten osiąga się, stosując iteracyjne rundy, 
w których ekspertom sekwencyjnie dostarczane są kwestionariusze, uzupełniane informacją zwrotną z poprzednich rund. Mechanizm ten umożliwia zebranie spornych opinii i ocen, co w skojarzeniu z relacją zwrotną, ułatwia dojście do konsensusu, zwanego efektem delfickim (Powell, 2003: 378). Metoda Delphi polega na co najmniej dwukrotnym ankietowaniu określonej grupy ekspertów.

Metoda Delphi jest rodzajem badania eksperckiego, w którym ,ludzkie sądy traktuje się jako uprawniony i użyteczny wkład w formułowanie prognoz na temat teraźniejszości i przyszłości lub w wybór metod rozwiązania problemów w sytuacji niepewności” (Wyrwicka i in. 2011: 11). Użyteczność tej metody jest szczególnie duża dla zjawisk rozwojowych, na temat których nie istnieją żadne wiarygodne dane, a także w przypadku, gdy zewnętrzne czynniki mają zdecydowany wpływ na sytuację lub argumenty społeczne mogą dominować nad ekonomicznymi bądź technicznymi czynnikami.

Badanie z wykorzystaniem metody Delphi dzieli się na 4 główne etapy: przygotowanie tez i formularzy badawczych oraz zaproszenie ekspertów, dystrybucję kwestionariuszy i ocenę stanów opisanych w tezach (co najmniej 2 rundy), analizę wyników, a w końcu wdrożenie rezultatów (za: Wyrwicka i in. 2011: 13).

Na potrzeby badania sieci gospodarczych Wielkopolski sformułowano na początku 2010 roku 37 tez (tabela 1).

Tabela 1

Tezy do badania metodą Delphi

(1) Inicjatywy proinnowacyjne $\mathrm{w}$ regionie po zaprzestaniu ich dotowania ze środków UE są kontynuowane z innych źródeł finansowania.

(2) Sektor nauki generuje wiedzę dla gospodarki.

(3) Produkty regionalnych środowisk naukowych nadają się do wdrożenia

(4) Istnienie w regionie lokalnych liderów i autorytetów profesjonalnych

(5) System informowania o dokonaniach naukowo-badawczych w regionie

(6) Promowanie innowacyjności przez media regionalne

(7) Wspieranie innowacyjności regionu przez współpracę międzynarodową

(8) Występowanie wspólnych inicjatyw z podmiotami spoza regionu (w Polsce)
(9) Występowanie wspólnych inicjatyw różnych przedsiębiorstw w regionie

(10) Występowanie wspólnych inicjatyw administracji lokalnej, przedsiębiorców i naukowców

(11) Istnienie wsparcia dla wdrożeń prototypowych do praktyki gospodarczej

(12) Wspieranie przekazu wiedzy przez izby gospodarcze i inne instytucje otoczenia biznesu

(13) Współfinansowanie prac badawczo-rozwojowych przez przedsiębiorstwa

(14) Wspieranie współpracy gospodarczej przez lokalne rozwiązania organizacyjno-prawne

(15) Wprowadzenie ulg podatkowych (dla pracodawców i osób fizycznych) stymuluje rozpowszechnianie wiedzy

(16) Pozyskiwanie spoza regionu gotowej do wykorzystania wiedzy 
Tab. 1 (cd.)

\begin{tabular}{|c|c|}
\hline $\begin{array}{l}\text { (17) Zapobieganie migracji zarobkowej do- } \\
\text { brych absolwentów z regionu }\end{array}$ & $\begin{array}{l}\text { (28) Akceptacja społeczna innowacyjności } \\
\text { i gotowość wspierania jej }\end{array}$ \\
\hline $\begin{array}{l}\text { (18) Zaufanie do kompetencji regionalnych } \\
\text { specjalistów }\end{array}$ & (29) Dostępność Internetu \\
\hline $\begin{array}{l}\text { (19) Zaufanie do instytucji administracji (pań- } \\
\text { stwowej, samorządowej) }\end{array}$ & $\begin{array}{l}\text { (30) Powszechność stosowania technologii te- } \\
\text { leinformatycznej w działalności gospodarczej }\end{array}$ \\
\hline (20) Wzajemne zaufanie przedsiębiorców & $\begin{array}{l}\text { (31) Kształcenie w miejscu pracy (inne niż stu- } \\
\text { dia i szkolenia) }\end{array}$ \\
\hline $\begin{array}{l}\text { (21) Chęć współdziałania z najlepszymi pod- } \\
\text { miotami gospodarczymi }\end{array}$ & $\begin{array}{l}\text { (32) Znaczenie odpowiedzialności za wyniki } \\
\text { własnej pracy jako podstawa budowania relacji } \\
\text { gospodarczych }\end{array}$ \\
\hline $\begin{array}{l}\text { (22) Poziom wiedzy o korzyściach we współ- } \\
\text { pracy z innymi podmiotami gospodarczymi }\end{array}$ & (33) Szacunek dla klienta \\
\hline $\begin{array}{l}\text { (23) Poziom wiedzy o zagrożeniach we współ- } \\
\text { pracy z innymi podmiotami gospodarczymi }\end{array}$ & $\begin{array}{l}\text { (34) Możliwość piętnowania patologicznych } \\
\text { zachowań w relacjach biznesowych }\end{array}$ \\
\hline $\begin{array}{l}\text { (24) Oddziaływanie podmiotu dominującego } \\
\text { na rozpowszechnianie wiedzy w sieci gospo- } \\
\text { darczej }\end{array}$ & $\begin{array}{l}\text { (35) Dopasowanie metod i programów kształ- } \\
\text { cenia do potrzeb praktyki gospodarczej }\end{array}$ \\
\hline $\begin{array}{l}\text { (25) Oddziaływanie wspólnych przedsięwzięć } \\
\text { realizowanych przez różne podmioty gospodar- } \\
\text { cze na rozpowszechnianie wiedzy }\end{array}$ & $\begin{array}{l}\text { (36) Poziom przygotowania nauczycieli i wy- } \\
\text { kładowców }\end{array}$ \\
\hline $\begin{array}{l}\text { (26) Oddziaływanie sieci gospodarczej na prze- } \\
\text { kaz sprawdzonej wiedzy }\end{array}$ & $\begin{array}{l}\text { (37) Poziom przygotowania trenerów do reali- } \\
\text { zacji szkoleń lub instruktażu }\end{array}$ \\
\hline
\end{tabular}

(27) Akceptacja społeczna przedsiębiorczości i gotowość wspierania jej

Źródło: Wyrwicka i in. 2011: 21-22.

Ten sam zestaw podlegał ocenie eksperckiej w 2014 roku. Każda z tez miała być oceniana według stanu w roku prowadzonych analiz (2010 dla pierwszego badania, 2014 dla drugiego badania) oraz w perspektywie roku 2030. Dla oceny sytuacji bieżącej przyjęto skalę od 1 do 5 , w której 5 oznaczało ocenę najwyższą. Odnośnie do przyszłości eksperci mieli wyrazić swoje oceny w skali 6-stopniowej, w której poszczególne wartości oznaczały:

- ocena 1 - sytuacja bardzo istotnie się pogorszy,

- ocena 2 - sytuacja istotnie pogorszy się,

- ocena 3 - sytuacja pogorszy się w stopniu nieznacznym,

- ocena 4 - sytuacja ulegnie nieznacznej poprawie,

- ocena 5 - sytuacja poprawi się,

- ocena 6 - sytuacja wyraźnie się poprawi.

Ekspertami w obu badaniach Delphi byli pracownicy sfery B+R, pracownicy oświaty, studenci, przedstawiciele mediów, przedstawiciele izb gospodarczych, 
pracownicy przedsiębiorstw, przedsiębiorcy, przedstawiciele administracji publicznej. Do badań zaproszono 140 ekspertów. Na wykresie 1 przedstawiono strukturę zawodów wykonywanych przez ekspertów oraz ich liczbę (dotyczy to tych, którzy odesłali wypełniony pierwszy kwestionariusz).

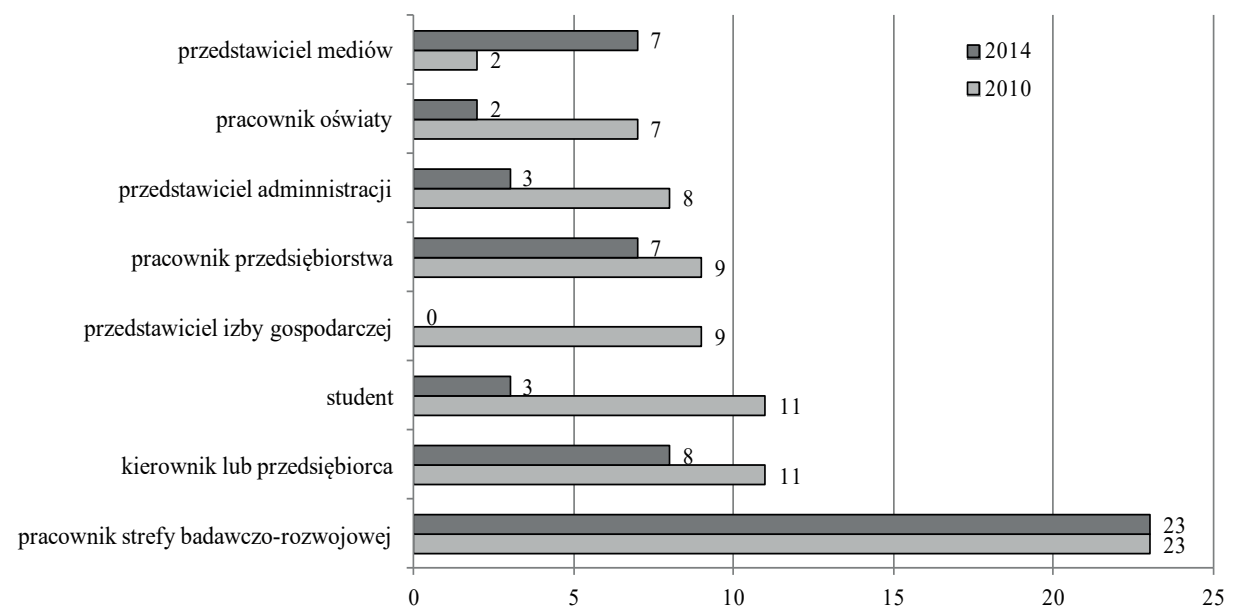

Wykres 1. Liczba i struktura zawodów wykonywanych przez ekspertów

Źródło: opracowanie własne na podstawie wyników badań.

W tabeli 2 przedstawiono liczbę odesłanych odpowiedzi po każdej z rund delfickich. Odniesione one zostały do badań zrealizowanych w 2010 oraz 2014 roku.

Zestawienie liczby odesłanych odpowiedzi w dwóch badaniach Delphi

\begin{tabular}{|c|c|c|}
\hline Etap badania & $\begin{array}{c}\text { Liczba odesłanych } \\
\text { odpowiedzi (2010) }\end{array}$ & $\begin{array}{c}\text { Liczba odeslanych } \\
\text { odpowiedzi (2014) }\end{array}$ \\
\hline Kwestionariusz 1 & 85 & 53 \\
\hline Kwestionariusz 2 & 67 & 32 \\
\hline Kwestionariusz 3 & 57 & nie dotyczy \\
\hline Kwestionariusz dodatkowy & 21 & nie dotyczy \\
\hline
\end{tabular}

Źródło: opracowanie własne na podstawie wyników badań.

Analizując wielkość grupy, która wypełniła oba kwestionariusze, zauważyć można, że jest to ponad 60\% ekspertów, którzy odesłali 1. kwestionariusz. Pomimo zmniejszenia się liczby uczestników, końcowa liczba ekspertów jest reprezentatywna w sensie statystycznym. 
W 2010 r. w badaniu wzięło udział 44\% kobiet i 56\% mężczyzn, zaś w roku $2014-43 \%$ kobiet i 57\% mężczyzn. Zapewnia to reprezentatywność i porównywalność wyników ze względu na płeć.

Analiza danych dotyczyć będzie odpowiedzi z trzeciej rundy dla badania przeprowadzonego w roku 2010 i drugiej rundy dla badania z roku 2014. Dane statystyczne, które są istotne przy badaniu metodą Delphi, to średnia arytmetyczna, mediana, kwartyl 1 i kwartyl 3. Wykorzystano również analizę czynnikową oraz analizę korespondencji.

\section{WYNIKI BADANIA - ANALIZA PORÓWNAWCZA}

\subsection{Ocena sytuacji bieżącej}

Pierwsza metoda analizy to analiza czynnikowa. Jest ona wielowymiarowa analizą statystyczną. Jej celem jest redukcja liczby badanych zmiennych do tych najbardziej istotnych dla badanego problemu (Ragin-Skorecka, 2009).

Analiza czynnikowa na podstawie uzyskanych wyników (średnia arytmetyczna) pozwoliła na określenie dwóch grup tez, które według respondentów w najwyższym stopniu charakteryzują Wielkopolskę w roku 2010. Należą do nich:

1) relacje między uczestnikami sieci gospodarczych (pierwszy czynnik):

- T1: Inicjatywy proinnowacyjne w regionie po zaprzestaniu ich dotowania ze środków UE są kontynuowane z innych źródeł finansowania.

- T2: Sektor nauki generuje wiedzę dla gospodarki.

- T4: Istnienie w regionie lokalnych liderów i autorytetów profesjonalnych.

- T18: Zaufanie do kompetencji regionalnych specjalistów.

- T21: Chęć współdziałania z najlepszymi podmiotami gospodarczymi.

- T22: Poziom wiedzy o korzyściach we współpracy z innymi podmiotami gospodarczymi.

- T24: Oddziaływanie podmiotu dominującego na rozpowszechnianie wiedzy w sieci gospodarczej.

- T30: Powszechność stosowania technologii teleinformatycznych w działalności gospodarczej.

- T32: Znaczenie odpowiedzialności za wyniki własnej pracy jako podstawa budowania relacji gospodarczych.

- T34: Możliwość piętnowania patologicznych zachowań w relacjach biznesowych.

- T35: Dopasowanie metod i programów kształcenia do potrzeb praktyki gospodarczej.

- T37: Poziom przygotowania trenerów do realizacji szkoleń lub instruktażu.

2) współpraca i promocja przedsiębiorczości (drugi czynnik):

- T6: Promowanie innowacyjności przez media regionalne. 
- T9: Występowanie wspólnych inicjatyw różnych przedsiębiorstw w regionie.

- T12: Wspieranie przekazu wiedzy przez izby gospodarcze i inne instytucje otoczenia biznesu.

- T13: Współfinansowanie prac badawczo-rozwojowych przez przedsiębiorstwa.

- T14: Wspieranie współpracy gospodarczej przez lokalne rozwiązania organizacyjno-prawne.

- T16: Pozyskiwanie spoza regionu gotowej do wykorzystania wiedzy.

- T19: Zaufanie do instytucji administracji (państwowej, samorządowej).

- T26: Oddziaływanie sieci gospodarczej na przekaz sprawdzonej wiedzy.

- T27: Akceptacja społeczna przedsiębiorczości i gotowość wspierania jej.

- T29: Dostępność Internetu.

- T36: Poziom przygotowania nauczycieli i wykładowców.

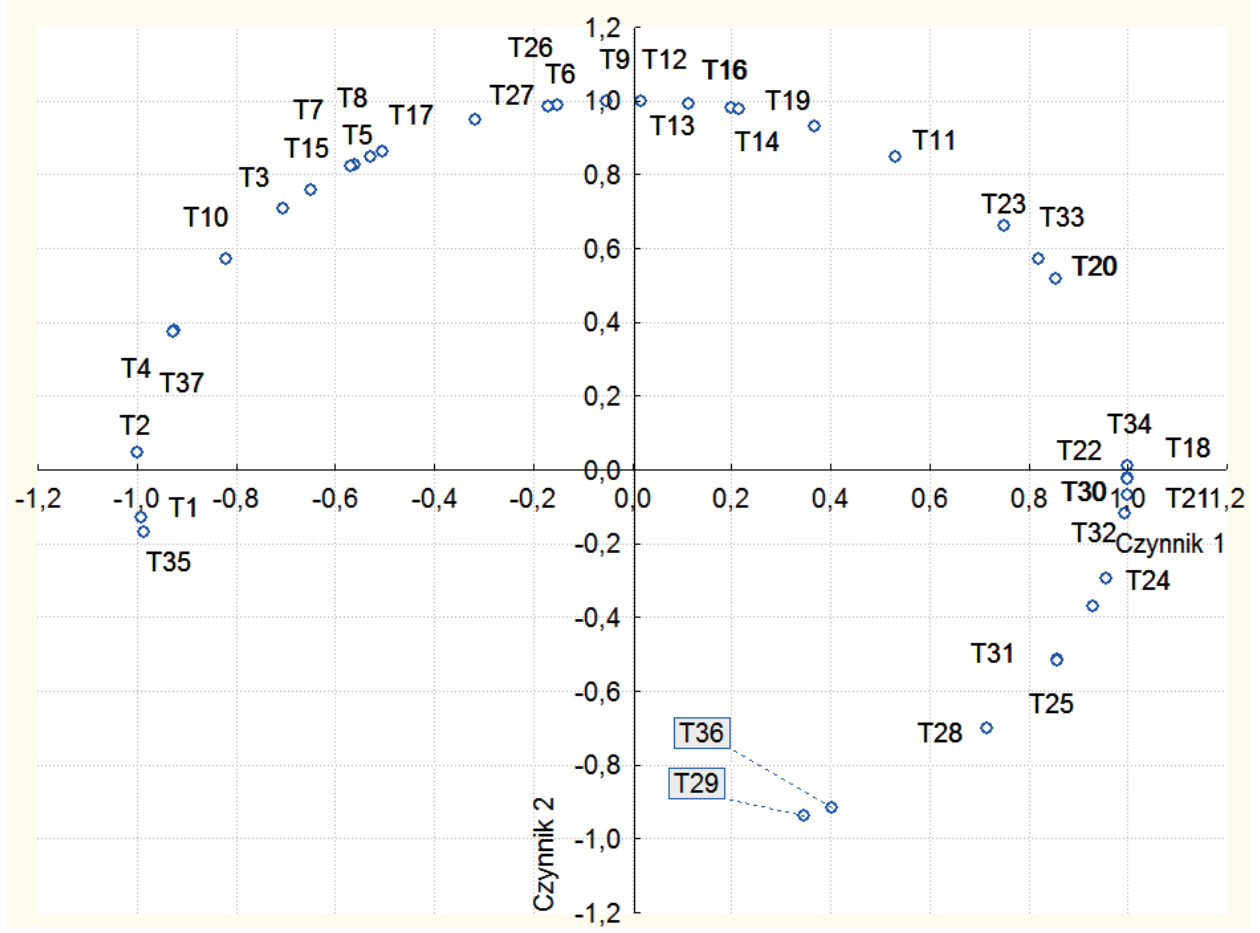

Wykres 2. Wyniki analizy czynnikowej dla ocen tez w roku 2010

Źródło: opracowanie własne na podstawie badań Delphi

Otrzymane grupy czynników pokazane są na wykresie 2 (czynnik 1 - oś pozioma, czynnik 2 - oś pionowa). Wykonana analiza wskazuje, że 37 zmiennych 
(tez) można zredukować do 23, które w najlepszym stopniu charakteryzują Wielkopolskę w roku 2010.

Wyniki analizy czynnikowej dla danych z roku 2014 nie pozwalają na redukcję liczby tez. Otrzymane korelacje występujące między tezami są albo doskonałą korelacją ujemną (wartość -1) albo doskonałą korelacją dodatnią (wartość +1) - tabela 3.

Tabela 3

Korelacje dla średniej przy ocenie tez w roku 2014

\begin{tabular}{|c|c|}
\hline Teza & Rodzaj korelacji \\
\hline T1, T4, T5, T6, T7, T8, T9, Т16, Т22, T23, Т24, Т30, Т31, Т32, Т35 & Doskonale dodatnia $(+1)$ \\
\hline 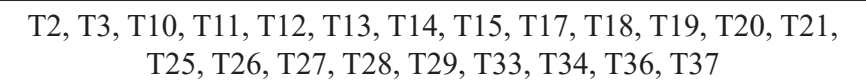 & Doskonale ujemna $(-1)$ \\
\hline
\end{tabular}

Źródło: opracowanie własne na podstawie wyników badań Delphi z roku 2014

Otrzymane wyniki wskazują, że istnieje ścisła zależność między badanymi tezami w ocenach ekspertów zarówno z roku 2014, jak i w perspektywie lat 2020 i 2030.

W roku 2010 eksperci uznali, że można wybrać 23 tezy, które opisują Wielkopolskę. Większość tych tez odnosi się do innowacyjności. Badanie z roku 2014 nie pozwoliło jednak na redukcję tez. Eksperci uznali bowiem, że są one jednakowo ważne i wszystkie powinny zostać poddane analizie.

Drugą wybraną metodą analizy danych jest analiza korespondencji, dzięki której są identyfikowane jednoczesne wystąpienia poszczególnych kategorii rozpatrywanych zmiennych (średnia arytmetyczna oceny dla każdej tezy). Wyniki analizy są przedstawiane graficznie w postaci punktów obrazujących kategorie cech na wykresie (Ragin-Skorecka, 2011).

$\mathrm{Na}$ wykresie 3 pokazano analizę korespondencji dla średniej arytmetycznej obliczonej dla każdej tezy ocenianej w roku 2010. Na tej podstawie można wnioskować, że:

- wyniki otrzymane w każdym kwestionariuszu są do siebie podobne (zbliżona odległość od środka układu odniesienia),

- największe różnice ocen wystąpiły dla tez (zaznaczone kołem):

- T8: Występowanie wspólnych inicjatyw z podmiotami spoza regionu.

- T15: Wprowadzenie ulg podatkowych (dla pracodawców i osób fizycznych) stymuluje rozpowszechnianie wiedzy.

- T20: Wzajemne zaufanie przedsiębiorców.

- T21: Chęć współdziałania z najlepszymi podmiotami gospodarczymi.

- T35: Dopasowanie metod i programów kształcenia do potrzeb praktyki gospodarczej. 


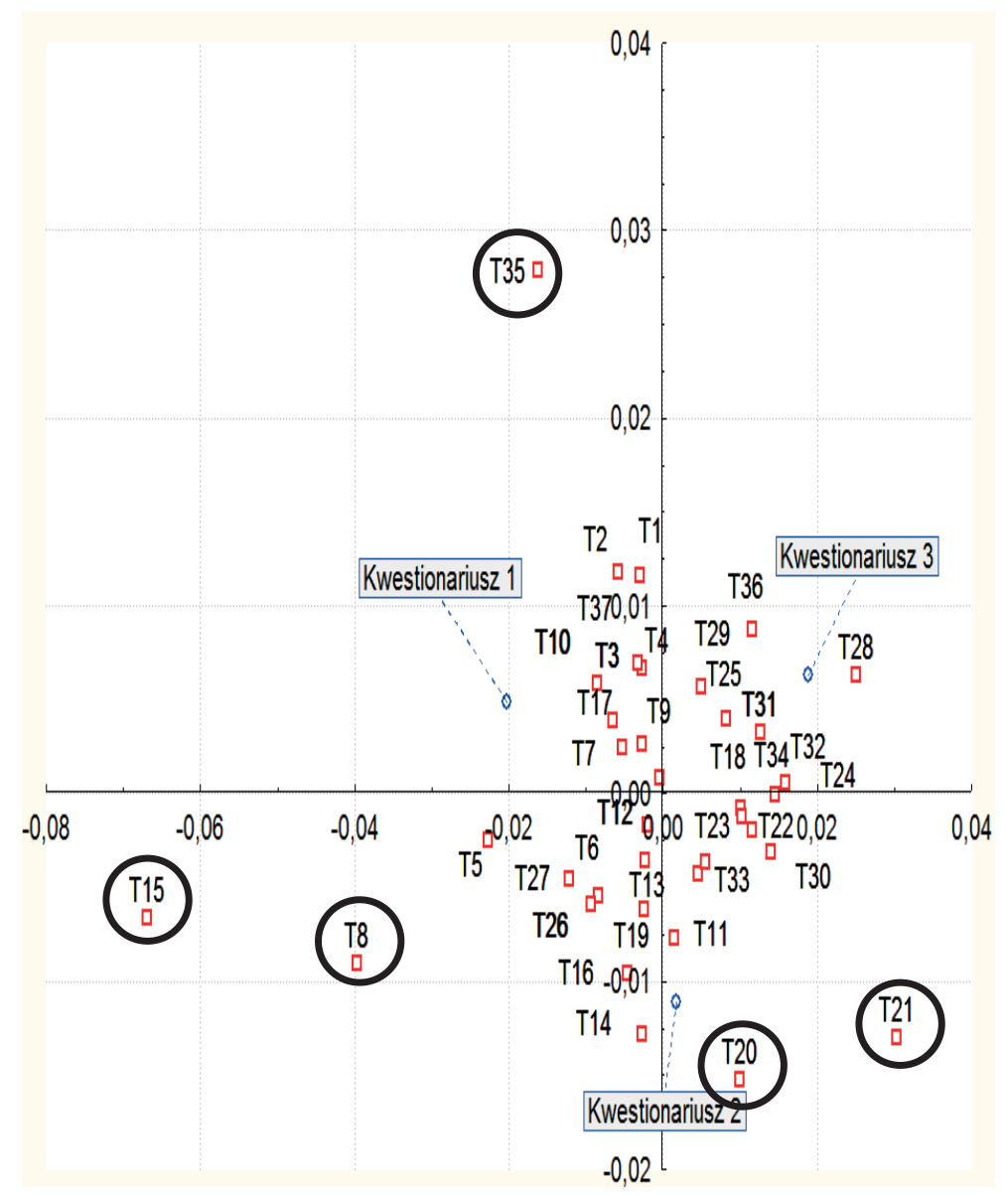

Wykres 3. Analiza korespondencji dla średniej arytmetycznej dla oceny w roku 2010

Źródło: opracowanie własne na podstawie badań Delphi z roku 2010

Na wykresie 4 pokazano wyniki analizy korespondencji dla średniej obliczonej dla każdej tezy ocenianej w roku 2014. Na jego podstawie można określić grupy tez podobnych do siebie ze względu na średnie oceny. Na podstawie analizy można wnioskować, że:

- najbardziej zgodne oceny ekspertów są dla tez: T2, T3, T7, T8, T10, T16, T20, T21, T24, T25, T26, T28, T29, T36, T37 (grupa tez zaznaczona ciągłą linią),

- większe różnice w ocenach ekspertów są dla tez pozostałych - wyróżnić można 5 grup tez,

- największa rozbieżność (grupa tez zaznaczona linią kropkowaną) w ocenach ekspertów dotyczy tez: 
- T6: Promowanie innowacyjności przez media regionalne.

- T12: Wspieranie przekazu wiedzy przez izby gospodarcze $\mathrm{i}$ inne instytucje otoczenia biznesu.

- T13: Współfinansowanie prac badawczo-rozwojowych przez przedsiębiorstwa.

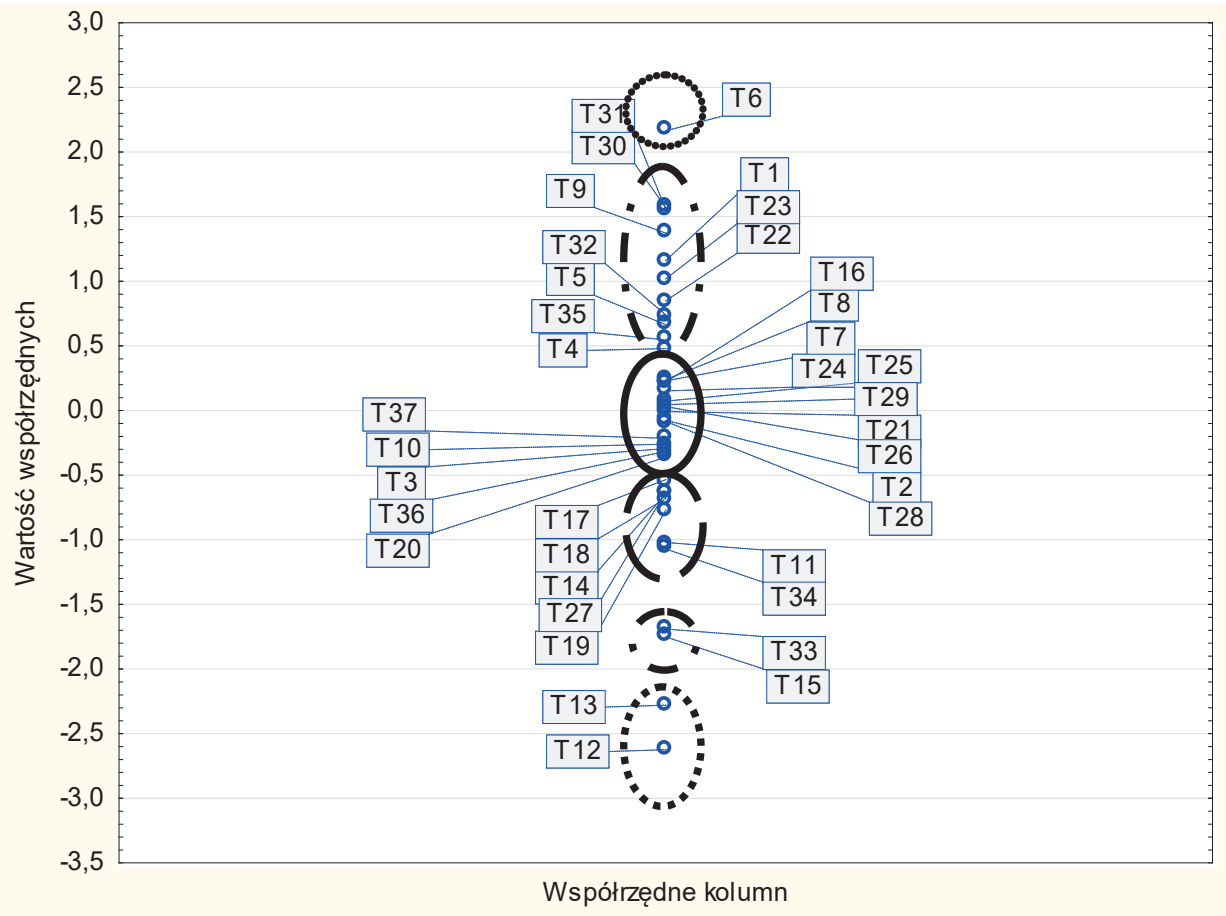

Wykres 4. Analiza korespondencji dla średniej arytmetycznej dla oceny w roku 2014

Źródło: opracowanie własne na podstawie wyników badań Delphi z roku 2014

W ocenie stanu w roku 2014 ujawniły się mniejsze rozbieżności w ocenach ekspertów niż w roku 2010. Zmieniły się również tezy, dla których te duże rozbieżności się pojawiają.

Na wykresie 5 przedstawiono dynamikę zmian oceny ekspertów dla oceny tez w roku 2010 i 2014. Analizując dane, zauważyć można, że eksperci w roku 2014 gorzej oceniają następujące tezy:

- T12: Wspieranie przekazu wiedzy przez izby gospodarcze i inne instytucje otoczenia biznesu.

- T13: Wspólfinansowanie prac badawczo-rozwojowych przez przedsiębiorstwa.

- T17: Zapobieganie migracji zarobkowej dobrych absolwentów z regionu.

- T19: Zaufanie do instytucji administracji (państwowej, samorządowej). 
Z kolei lepiej w porównaniu z rokiem 2010 oceniane są tezy:

- T6: Promowanie innowacyjności przez media regionalne.

- T9: Występowanie wspólnych inicjatyw różnych przedsiębiorstw w regionie.

- T11: Istnienie wsparcia dla wdrożeń prototypowych do praktyki gospodarczej.

- T34: Możliwość piętnowania patologicznych zachowań w relacjach biznesowych.

- T35: Dopasowanie metod i programów kształcenia do potrzeb praktyki gospodarczej.

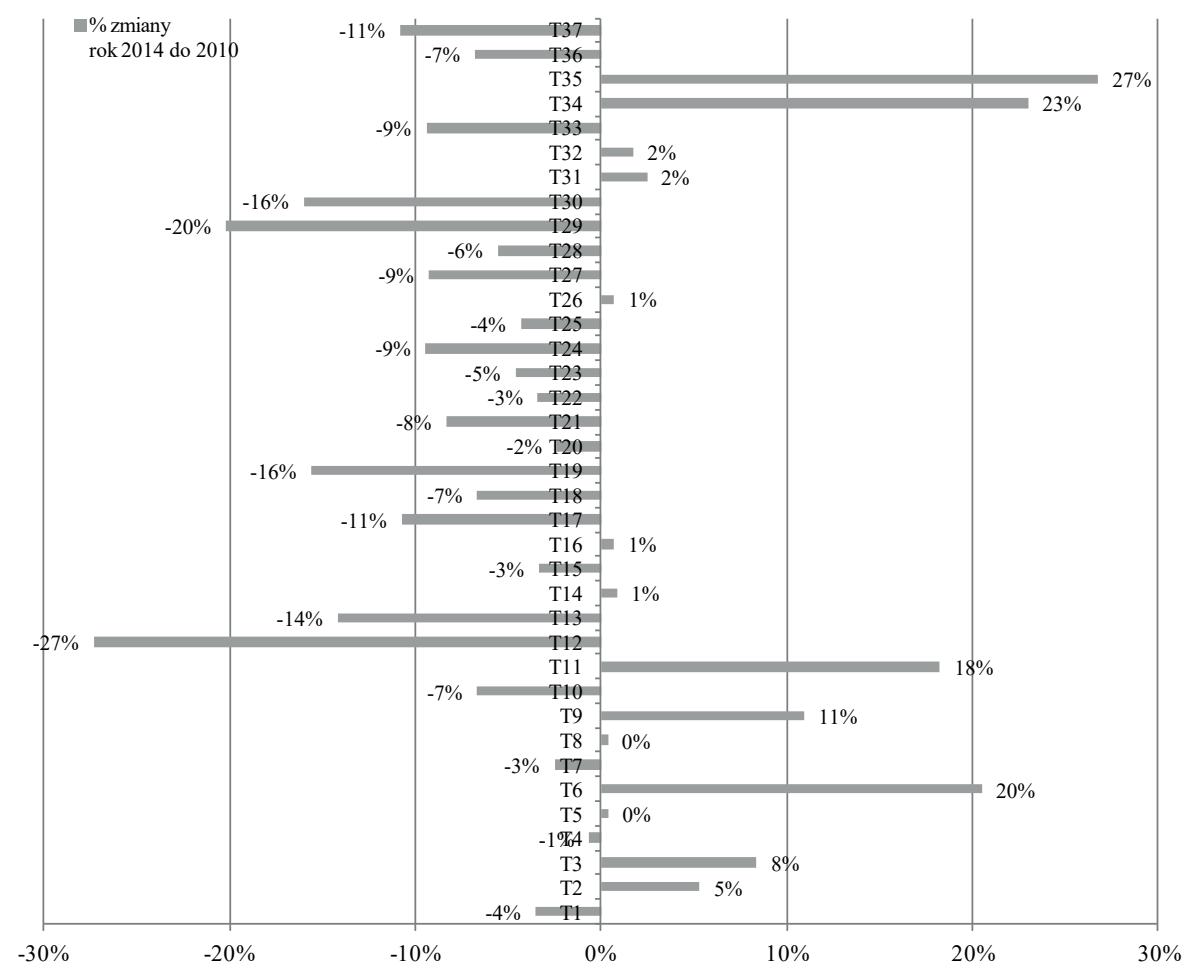

Wykres 5. Dynamika zmian oceny ekspertów dla tez w roku 2010 i 2014

Źródło: opracowanie własne na podstawie wyników badań Delphi z roku 2010 i 2014

W kontekście kształtowania innowacyjności Wielkopolski pozytywnym zjawiskiem jest dopasowywanie programów kształcenia do oczekiwań praktyki biznesowej, rozwój wsparcia dla projektów ze styku nauka i biznes, możliwość piętnowania patologicznych zachowań w relacjach biznesowych oraz promowanie przez media regionalne innowacyjności. Niepokoi jednak pogorszenie ocen dla instytucji otoczenia biznesu (szczególnie w odniesieniu do izb gospodarczych), 
spadające zaufanie do instytucji administracji, słabe współfinansowanie prac badawczo-rozwojowych w przedsiębiorstwach oraz brak działań zapobiegających migracji absolwentów.

\subsection{Ocena przyszłości}

Badania metodą Delphi mają dać odpowiedź na pytanie: jak będzie wyglądała przyszłość? W badaniu przyjęto perspektywę rozwoju do roku 2030. Do oceny przyszłości Wielkopolski wybrano statystykę mediana.

$\mathrm{Na}$ wykresie 6 przedstawiono analizę korespondencji dla mediany wskazanej dla roku $2030 \mathrm{w}$ badaniach prowadzonych w roku $2010 \mathrm{i}$ w roku 2014. Przedstawione punkty reprezentują oceniane tezy, ich współrzędne to wartość współczynnika kontyngencji (zależność między dwiema zmiennymi jakościowymi). W analizie korespondencji uwzględnia się odległość zmiennych od początku układu współrzędnych.

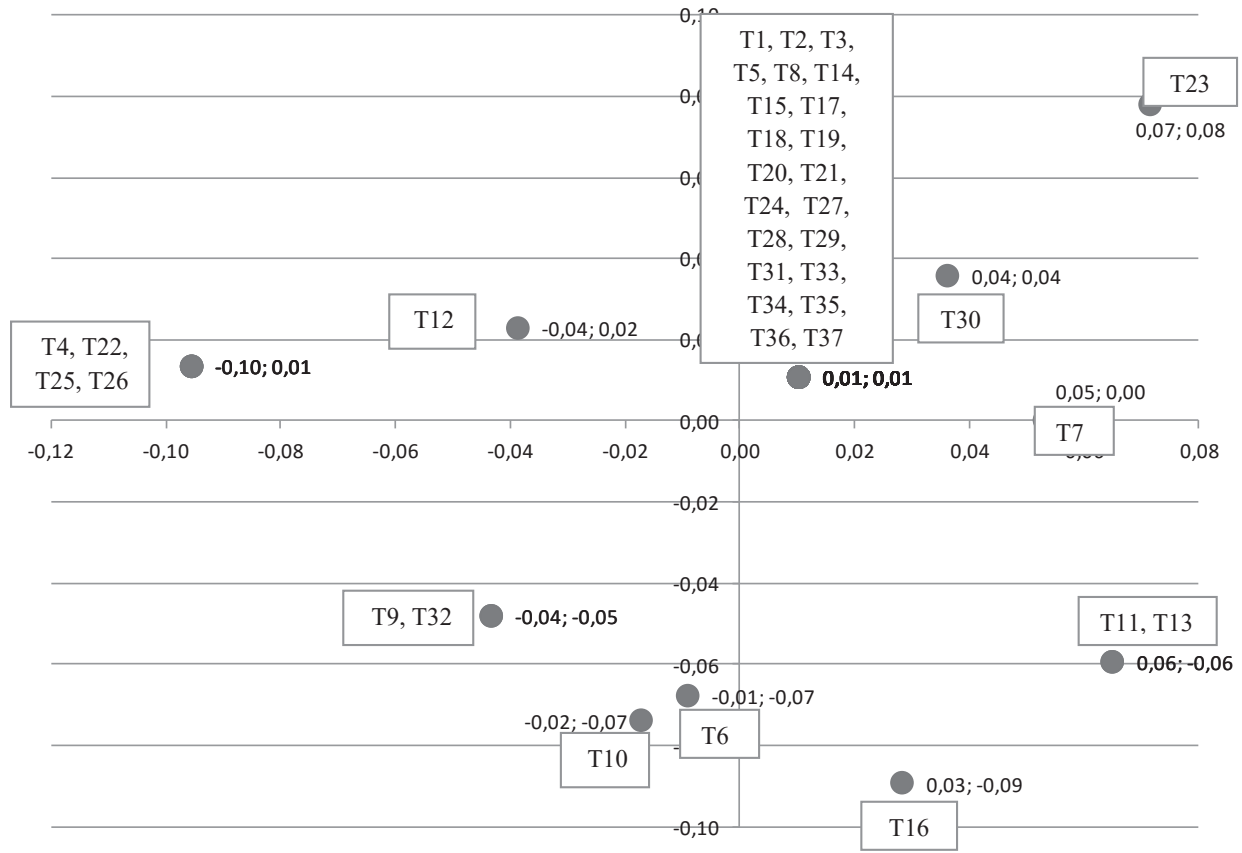

Wykres 6. Analiza korespondencji dla mediany przy ocenie tez w perspektywie roku 2030

Źródło: opracowanie własne na podstawie badań Delphi

Analiza pozwala zauważyć, że dla większości tez eksperci opiniujący sytuację w perspektywie roku 2030 podczas badań realizowanych w roku 2010 i 2014 
są zgodni w ocenach. Największa różnica w ocenie rozwoju sytuacji opisanej tezami w perspektywie roku 2030 dotyczy tez:

- T4: Istnienie w regionie lokalnych liderów i autorytetów profesjonalnych.

- T16: Pozyskiwanie spoza regionu gotowej do wykorzystania wiedzy.

- T10: Występowanie wspólnych inicjatyw administracji lokalnej, przedsiębiorców i naukowców.

- T11: Istnienie wsparcia dla wdrożeń prototypowych do praktyki gospodarczej.

- T13: Współfinansowanie prac badawczo-rozwojowych przez przedsiębiorstwa.

- T22: Poziom wiedzy o korzyściach we współpracy z innymi podmiotami gospodarczymi.

- T23: Poziom wiedzy o zagrożeniach we współpracy z innymi podmiotami gospodarczymi.

- T25: Oddziaływanie wspólnych przedsięwzięć realizowanych przez różne podmioty gospodarcze na rozpowszechnianie wiedzy.

- T26: Oddziaływanie sieci gospodarczej na przekaz sprawdzonej wiedzy.

Eksperci przewidują, że w roku 2030 nastąpi rozwój w każdym z obszarów opisywanych przez tezy. Sytuacja wyraźnie się poprawi w związku z dostępnością Internetu (T29) oraz powszechnością stosowania technologii teleinformatycznej w działalności gospodarczej (T30). Pozostałe tezy otrzymały wskazania: poprawią się lub nieznacznie się poprawią.

Po przeanalizowaniu wskazań ekspertów zauważono, że przez 4 lata, które upłynęły między kolejnymi badaniami, pogorszyła się ocena możliwości poprawy sytuacji dla sześciu następujących tez:

- T4: Istnienie w regionie lokalnych liderów i autorytetów profesjonalnych.

- T9: Występowanie wspólnych inicjatyw różnych przedsiębiorstw $\mathrm{W}$ regionie.

- T22: Poziom wiedzy o korzyściach we współpracy z innymi podmiotami gospodarczymi.

- T25: Oddziaływanie wspólnych przedsięwzięć realizowanych przez różne podmioty gospodarcze na rozpowszechnianie wiedzy.

- T26: Oddziaływanie sieci gospodarczej na przekaz sprawdzonej wiedzy.

- T32: Znaczenie odpowiedzialności za wyniki własnej pracy jako podstawa budowania relacji gospodarczych.

Dla wyżej wymienionych tez odnotowano zmianę oceny z sytuacji „poprawi się" (5 pkt) na ocenę sytuacja „,poprawi się w niewielkim stopniu” (4 pkt). Taka weryfikacja opinii ekspertów wynika prawdopodobnie ze zmian, które zaszły w ciągu ostatnich lat w otoczeniu gospodarczym. Są to m.in. takie zjawiska, jak:

- brak liderów i autorytetów profesjonalnych,

- niechęć do stawania się autorytetem,

- niechęć do dzielenia się wiedzą profesjonalną, 
- uwarunkowania polityczne,

- brak wzorcowych sieci gospodarczych działających w regionie,

- ciągłe niskie zaufanie na poziomie międzyorganizacyjnym,

- brak promowania dobrych wzorców przez media,

- brak wyraźnego wsparcia z instytucji otoczenia biznesu,

- nieświadomość możliwości otrzymania wsparcia przy współdziałaniu.

Nie pojawiły się zmiany w ocenie ekspertów, które wskazywałyby na lepszy rozwój sytuacji opisywanej daną tezą.

\section{PODSUMOWANIE}

Kontynuując badania nad przyszłością Wielkopolski, które - zdaniem autorek - powinny być wykonywane cyklicznie, podjęto w 2014 roku kolejne powtórzenie analiz Delphi, w których uczestniczyło N=53 ekspertów. Ocenili oni stan na rok 2014 oraz sformułowali opinie dotyczące przewidywanych sytuacji w roku 2030, które opisane zostały w formie 37 tez (tych samych, co w badaniu prowadzonym roku 2010).

Ocena zrealizowana dla roku 2014 wykazała niewielkie pogorszenie w stosunku do roku 2010 sytuacji opisanej czterema tezami (dotyczącymi: wspierania przekazu wiedzy przez izby gospodarcze i inne instytucje otoczenia biznesu, współfinansowania prac badawczo-rozwojowych przez przedsiębiorstwa, zapobiegania migracji zarobkowej dobrych absolwentów z regionu, zaufania do instytucji administracji), a także poprawę w $2014 \mathrm{w}$ stosunku do roku 2010 sytuacji opisanych pięcioma tezami (promowanie innowacyjności przez media regionalne, występowanie wspólnych inicjatyw różnych przedsiębiorstw w regionie, wsparcie dla wdrożeń prototypowych do praktyki gospodarczej, możliwość piętnowania patologicznych zachowań w relacjach biznesowych oraz dopasowanie metod i programów kształcenia do potrzeb praktyki gospodarczej). Takie zmiany ocen mogą być efektem zmiany priorytetów dofinansowania ze środków unijnych oraz niewielkiej reakcji władz samorządowych na wnioski z prowadzonych w regionie badań foresight.

Analizy zaprezentowane w opracowaniu ukazały niewielkie pogorszenie poziomu oceny sytuacji przewidywanej dla 2030 roku w odniesieniu do sześciu spośród 37 tez. Mimo że jest to tylko 16\% opiniowanych stwierdzeń, ich pojawienie niepokoi. Słabe perspektywy odnośnie do tworzenia i rozwoju sieci gospodarczych potwierdza fakt malejącej nadziei na pojawienie się lokalnych liderów, a w perspektywie promocji (preferencji dla finansowania) wspólnych przedsięwzięć klastrowych - pogarszająca się w opinii respondentów gotowość do współpracy i podejmowania wspólnych inicjatyw administracji, sektora nauki i przedsiębiorców. Optymizmu nie budzą również ani większy sceptycyzm odnośnie do usprawniania przekazu sprawdzonej wiedzy w sieciach gospodarczych, ani mniejsze przekonanie o odpowiedzialności za wyniki pracy w realiach gospodarczych. 
Poprawę opinii związanej ze stanem na rok 2030 odnotowano tylko w odniesieniu do dwóch tez:

- T30: Powszechność stosowania technologii teleinformatycznej w działalności gospodarczej (mediana z 5 na 6), co zwiastuje coraz szersze zastosowania Internetu.

- T36: Poziom przygotowania nauczycieli i wykładowców (mediana z 4 na 5), co - przy obecnym niżu demograficznym i popsutym przez środki unijne rynku szkoleniowym - może świadczyć o selekcji grona osób podejmujących działalność edukacyjną.

Zdaniem autorek generalna ocena możliwości proinnowacyjnego rozwoju Wielkopolski w perspektywie roku 2030 nieznacznie się pogorszyła.

\section{BIBLIOGRAFIA}

Dalkey N.C., Helmer O. (1963), An Experimental Application of the Delphi Method to the Use of Experts. „Management Science”, vol. 9, no. 3.

Gavigan J.P., Scapolo F., Keenan M., Miles I., Farhi F., Lecoq D., Capriati M., Bartolomeo T. Di (2001), A Practical Guide to Regional Foresight. Report EUR 20128 EN, Foresight for Regional Development Network (FOREN), European Communities. http://foresight.jrc.ec.europa.eu/documents/eur20128en.pdf (25.11.2012).

http://www.eurosfaire.prd.fr/7pc/doc/1269596555_efmn_mapping_foresight_en.pdf (20.01.2013). Magruk A., Jańczuk E. (2009), Typologia i klasyfikacja metod badawczych foresightu technologicznego. J. Czech-Rogosz (red.), Koniunktura gospodarcza a reakcje podmiotów gospodarujacych, Wydawnictwo Akademii Ekonomicznej, Katowice.

Nazarko J. (2013), Regionalny foresight gospodarczy. Metodologia i instrumentarium badawcze. Związek Pracodawców Warszawy i Mazowsza, Warszawa.

Popper R.(2009), Mapping Foresight: Revealing how Europe and other world regions navigate into the future, EFMN, Publications Office of the European Union, Luxembourg.

Ragin-Skorecka K. (2009), Research on the structure of the internal organizational identity. Ka1kowska J., Włodarkiewicz-Klimek H. (eds.). Management Enterprises. Social aspects. Publishing House of Poznan University of Technology, Poznan.

Ragin-Skorecka K. (2011), Analiza subregionów w Wielkopolsce $w$ aspekcie wybranych cech tożsamości regionu. Wyrwicka M. K. (red.), Budowa scenariuszy transformacji wiedzy wspierających innowacyjna Wielkopolskę. Tom I. Badania uzupetniające, Wydawnictwo Politechniki Poznańskiej. Poznań.

Rogut A., Piasecki B. (2001), Podręcznik ewaluatora projektów foresight. Ministerstwo Nauki i Szkolnictwa Wyższego. Warszawa.

Safin K.(2011), Foresight jako metoda kształtowania przyszłości. Identyfikacja potencjału i zasobów Dolnego Ślaska w obszarze nauka i technologie na rzecz poprawy jakości życia. Uniwersytet Ekonomiczny we Wrocławiu. Wrocław.

Wyrwicka M. (red.) (2011), Raport z badań metoda Delphi do projektu FORESIGHT „Sieci Gospodarcze Wielkopolski" - scenariusze transformacji wiedzy wspierajace innowacyjna gospodarkę. Wydawnictwo Politechniki Poznańskiej. Poznań.

Wyrwicka M. K. (2014), Raport z badań „Foresight - sieci gospodarcze”. Wielkopolski 503213/11/140/DSPB/4130 (opracowanie niepublikowane). 
Katarzyna Ragin-Skorecka, Magdalena Krystyna Wyrwicka

\title{
COMPARATIVE ANALYSIS DELPHI RESEARCH RELATED TO WIELKOPOLSKA`S INNOVATION
}

\begin{abstract}
In article was presented a comparative analysis of the results the Delphi analysis conducted in 2010 and 2014. Problem research was Wielkopolska's innovation and business networking opportunities, especially in view of 2030. The correspondence analysis and factor analysis was according to the results.
\end{abstract}

Keywords: foresight, Delphi research, innovation 